\title{
DEVELOPING ENTREPRENEURIAL COMPETENCY OF FUTURE QUALIFIED SPECIALISTS USING SELF-MANAGEMENT TECHNOLOGY
}

\author{
Liudmyla Yershova, \\ Doctor of Pedagogic Sciences, Associate Professor, Deputy Head of the Institute of Vocational Education and Training of NAES \\ of Ukraine \\ https://orcid.org/0000-0002-2346-5842, e-mail: 1.yershova@hotmail.com
}

\begin{abstract}
.
Relevance: market relations reforms in Ukraine determine changes in the system of national professional education. They primarily refer to the need to prepare young specialists for successful personal and professional self-realization under the conditions of small business development.

Aim: the paper aims to theoretically justify the expediency of using self-management technology in the process of developing entrepreneurial competency in future specialists under the conditions of changing market relations in Ukraine and intensive development of small business.

Methods: external analysis of selected sources (to determine the historical circumstances and motives behind their creation and functioning as elements of specific social relations) and internal analysis (to study the characteristics of particular documents).

Results: the paper shows that specific changes in economic relations lead to dynamic transformational shifts in personal values of modern students. The category of time becomes crucial for young specialists in the context of moving from the post-industrial to the information society, characterized by innovations and rapid changes in working conditions. Self-management is becoming a vital skill of the young generation since it implies time management and self-development. International and national documents emphasize the importance of developing career, entrepreneurial and other key competencies, necessary for building a successful professional career and self-employment under the conditions of small business development. At the same time, Ukrainian professional education schools are not ready to prepare young people for the rational use of their personal and time resources.

Conclusions: Self-management technology is one of the most promising tasks for developing entrepreneurial competency under the conditions of small business development. The programme, titled «The Basics of Innovative Entrepreneurship», has been developed to overcome the imbalance between the development of professional and key competencies and the improvement of psycho-pedagogical and legal training of young specialists for self-employment under the conditions of changing market relations. Its essential component is self-management technology. The paper also describes the main components of this technology (gnostic, designing, communicative, organizational, constructive), as well as the stages of its implementation.
\end{abstract}

Keywords: professional education, self-management, key competencies, career competency, entrepreneurial competency.

Introduction. The changes in the economic paradigm of the development of society and the state objectively determine the need to reform the educational paradigm. The Pro-European Development of Ukraine defines the vectors for reforming all spheres of life, including education. Therefore, the state determines the main areas of reforming market relations, and the education system aims to prepare young specialists for successful personal and professional self-realization under the new market conditions. The state and the government use the world best practices in building economic relations when implementing the national economic policy. Thus, educational managers should 
adhere to fundamental educational trends which can maximize the professional adaptation and integration of the young generation of Ukrainian specialists in the system of Ukrainian and international relations. The Pro-European Development of Ukraine consolidates the democratic gains of the Ukrainian people, including economic freedoms and freedom of enterprise. This socio-economic phenomenon is decisive in the development of a powerful middle class that underlies the development of a democratic society. It is a class of successful people who can provide for themselves and their families since it is necessary to meet not only the primary vital needs but also social and spiritual ones. The development of such a specialist who has professional, entrepreneurial, social, civic and other key competences is the primary goal of the national system of professional education.

Thus, it is essential to study the conditions and elaborate specific mechanisms for developing entrepreneurial competency in future specialists in Ukrainian professional (vocational) education schools and professional pre-higher education institutions. Considerable attention should be paid to self-management as a set of processes, rational forms, methods and techniques designed to ensure cognition and self-development of the individual, effective monitoring of his or her activities and results, scientific focus of labour and develop readiness for success, drafting and implementation of a strategy of personal and career development.

The paper aims to theoretically justify the expediency of using self-management technology in the process of developing entrepreneurial competency in future specialists under the conditions of changing market relations in Ukraine and intensive development of small business.

Methods. The following classical methods have been used to achieve the set aim: external analysis of selected sources (to determine the historical circumstances and motives behind their creation and functioning as elements of specific social relations), internal analysis (to study the characteristics of particular documents), comparison (to identify the differences and similarities in approaches to defining the role of key competencies), generalization (to select relevant pedagogical tools for developing entrepreneurial competency under the conditions of small business development).

Sources: international documents (Copenhagen Declaration (2002), Bruges Communiqu? (2010), proceedings of international economic forums; laws of Ukraine ("On Education" (2017), "On Vocational Education and Training" (1998), "On Development and State Support for Small and Medium-Sized Entrepreneurship in Ukraine" (2012); other national documents (The National Programme for the Pro- motion of Small Business Development in Ukraine (2000), The National Doctrine of Education Development in Ukraine in the 21st Century (2002), The National Strategy for the Development of Education in Ukraine for 2012-2021 (2009), The Sustainable Development Strategy Ukraine - 2020 (2015), The New Ukrainian School Concept (2016), The Strategy for the Development of Small and Medium-Sized Entrepreneurship in Ukraine until 2020 (2017), The Mid-Term Government Priority Action Plan up to 2020 (2017); reports prepared by the laboratory of professional career at the Institute of VET of the NAES of Ukraine (2016-2018), analytical and statistical materials of the Verkhovna Rada Committee on Education, Science and Innovation, the Ministry of Education and Science of Ukraine, State Statistics Service of Ukraine, State Employment Service; Internet resources (HeadHunter, UNESCO Database, Eurostat Educational Statistics); publications of Ukrainian researchers on the issues of developing career, entrepreneurial and other key competences of future specialists (A. Alieksieieva, B. Dratver, D. Zakatnov, V. Machuskyi, V. Orlov, N. Pasichnyk, V. Radkevych et al.).

Results and discussion. A characteristic feature of economic reforms in the 21 st century is the humanization of economic terms. It is crucial to shift the emphasis from the generation of productive forces to the development of human capital, the transition from a knowledge-based educational paradigm to a competency-based philosophy of education. A working man becomes an unconditional participant in building economic relations. The changes in economic relations lead to dynamic transformational shifts in the values of modern pupils and students. Young people's perception of the role of knowledge, the status of education, professionalism, career and career success has changed tremendously (Yershov, 2018, pp. 163). All these changes are, to some extent, based on the changes in the temporal paradigm of professional growth. The category of time becomes crucial for young specialists in the context of moving from the post-industrial to the information society, characterized by innovations and rapid changes in working conditions. Self-management is becoming a vital skill of the young generation since it implies time management and self-development. In other words, self-management becomes one of the tops of pedagogical technologies.

One should pay particular attention to some of the most well-known conceptual approaches to defining this phenomenon: an optimal use of time (L. Zayvert), testing one's capabilities, overcoming personal limitations (D. Francis, M. Woodcock), self-development of a creative personality for self-realization in various activities (V. Andreiev), raising the level 
of one's business culture (O. Khrolenko), achieving personal success, career realization (B. Schwalbe, H. Schwalbe). Thus, the category of time is common to all concepts, incorporating the basic ideas of each approach to the strategy of the individual's personal and career development.

At the same time, such factors as the current state of vocational guidance for pupils, their preparation for the pursuit of a professional career, readiness for professional success and the opening of one's business reveal a significant pedagogical problem, that is the inability of young people to effectively manage their own time and develop their personality (Dratver et al., 2004; Zakatnov, 2007; 2009; 2015; Radkevych, 2012a; 2012b). A survey of pupils from professional (vocational) education schools conducted by the employees of the laboratory of professional career at the Institute of VET of the NAES of Ukraine (2016-2018) (Zakatnov, 2017) also shows the irrational approach of young people to the use of personal time.

The results of the survey show that $9.3 \%$ of pupils entered professional (vocational) education schools only because they were bored with school; $18.5 \%$ of them sought to simplify their entry to a higher education institution, and $7 \%$ of them failed to enter another educational institution. That is, $34.8 \%$ of pupils did not have a clear idea about the future profession when entering professional (vocational) education schools (see Fig. 1).

Spontaneity and impulsivity remain very powerful factors in the focusing of intellectual, physical and emotional efforts of the individual on the path to professional growth. The results of the survey show that $47.5 \%$ of pupils are unsure about the correctness of their choice; $6.2 \%$ of them recognize the complete mismatch between the profile of the chosen profession and their personal needs; $24.6 \%$ of them have significant doubts about the prestige of the chosen profession. These figures conceal the so-called long-delay time bomb for many young people (see Fig. 2). A person who has made a mistake in choosing a pro- fession loses not only time (since he or she is forced to retrain in the future, that is, to restart professional career), but also confidence (because he or she is aware of his or her lagging behind more successful peers). Uncertainty causes insecurities that hinder the development of both career and entrepreneurial competencies. In a digital society, managing time means managing one's life and success.

The study of pupils' motivation towards success allows classifying their motives into external and internal (see Table 1). The most powerful external motives for pupils are financial support and parents' connections (9\%). Internal factors based on higher-level needs have roughly equal percentages: professionalism and good education (13.4\%), self-confidence and high aspirations (13.8\%), clear life principles and goals (12.6\%), responsibility and personal standards (11.8\%), volition (11.5\%). One should pay specific attention to the percentage of qualities based on lower-level needs: flexibility, ability to adapt to changes (13\%) and ability "to play without rules", using all the means to achieve success $(8.7 \%)$, which are perceived by this category of pupils as most favourable for career success.

A gender-based approach to analyzing pupils' perceptions of factors in professional success reveals that male pupils (493) consider "playing without rules" as a factor of professional success more often than female pupils (418) (see Fig. 3).

It must be acknowledged that girls (678) are less confident in comparison with boys (765) which confirms the well-known statement that men are more likely to be at risk (see Fig. 4).

The experiment shows that pupils' perceptions of their careers are determined by personal characteristics, life goals, values and personality traits; gender characteristics; the level of aspirations and development of pupils' self-esteem; the characteristics of their cognition and emotional sphere; worldview, knowledge about the profession, people, society; traditions of family education, a financial

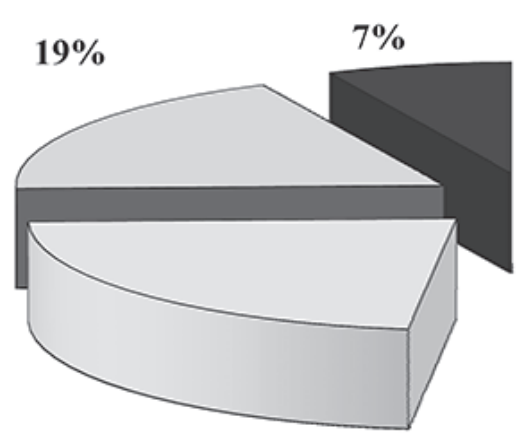

$23 \%$

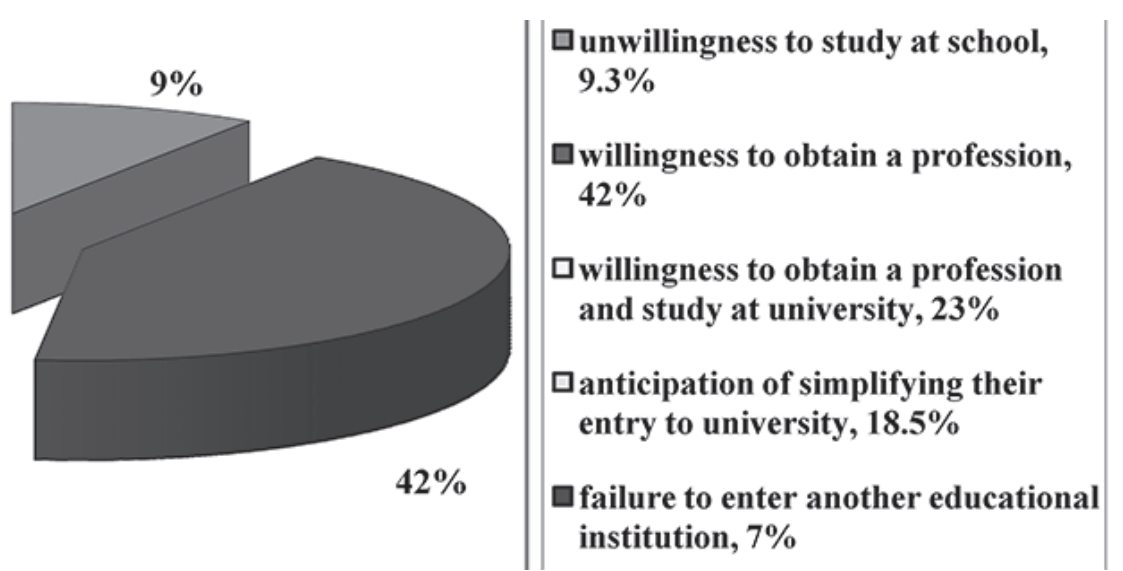

institution, $7 \%$

Fig. 1. Pupils'motives for entering professional (vocational) education schools (Zakatnov, 2017) 


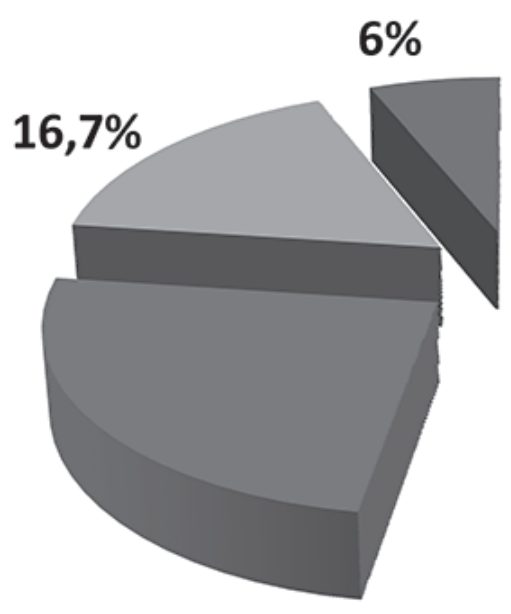

$24,6 \%$

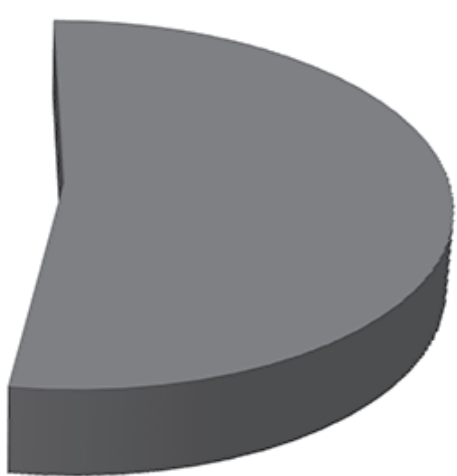

$52,5 \%$

Fig. 2. The relevance of the chosen profession to the personal needs of pupils from professional (vocational) education schools (based on the survey of 1690 pupils) (Zakatnov, 2017)

Table 1

Pupils' perceptions of the factors in professional success

Factors

Girls $\begin{aligned} & \text { Year } 1 \\ & \text { Boys Total Girls }\end{aligned}$ Boys Total

Year 3

Total \%

External factors

1 Financial security

2 A favourable situation

in the country

$\begin{array}{lll}134 & 131 & 265\end{array}$

$149 \quad 167 \quad 316$

$\begin{array}{lllll}154 & 198 & 352 & 933 & 9\end{array}$

3 Friendly ties

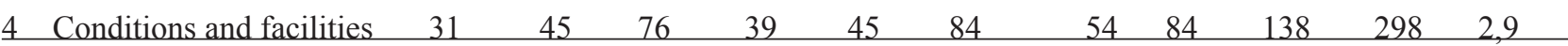

Total, external factor

$204 \quad 218 \quad 422$

$190 \quad 233 \quad 507$

$235 \quad 269 \quad 642$

$1571 \quad 15,1$

Internal factors

based on higher-level needs

5 Good education,

professionalism $\begin{array}{llllll}193 & 236 & 429 & 236 & 299 & 535\end{array}$ $218 \quad 218 \quad 436$ $1400 \quad 13.4$

6 Self-confidence, high

aspirations $\begin{array}{llllll}249 & 228 & 477 & 197 & 279 & 476\end{array}$ $\begin{array}{lllll}232 & 258 & 490 & 1443 & 13,8\end{array}$

7 Clear life principles

and goals $\begin{array}{llllll}183 & 257 & 440 & 169 & 267 & 436\end{array}$ $219 \quad 219 \quad 438$ $1314 \quad 12,6$

8 Responsibility

and personal standards

9 Volition $196 \quad 18$ $\begin{array}{llll}77 & 171 \quad 265 \quad 436\end{array}$ $\begin{array}{lllll}245 & 176 & 421 & 1234 & 11,8\end{array}$

Total internal factors

13219

$953 \quad 1093 \quad 2046 \quad 956$ based on lower-level needs

10 Flexibility, ability to adapt to changes $\begin{array}{llllll}268 & 195 & 463 & 181 & 189 & 370\end{array}$ $256 \quad 264 \quad 520$ $1353 \quad 13$

11 Ability "to play without rules", using all the means

\begin{tabular}{llllllllllll} 
to achieve success & 157 & 132 & 289 & 96 & 178 & 274 & 165 & 183 & 348 & 911 & 8,7 \\
\hline Total, internal factors 2 & 425 & 327 & 752 & 277 & 367 & 644 & 421 & 447 & 868 & 2264 & 21,7 \\
\hline Total & & & & & & & & & & 10423 & 100 \\
\hline
\end{tabular}




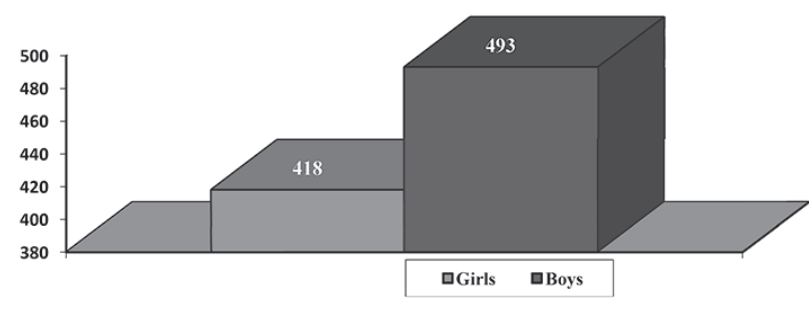

Fig. 3. Gender characteristics of pupils'views on "playing without rules" as a factor of professional success

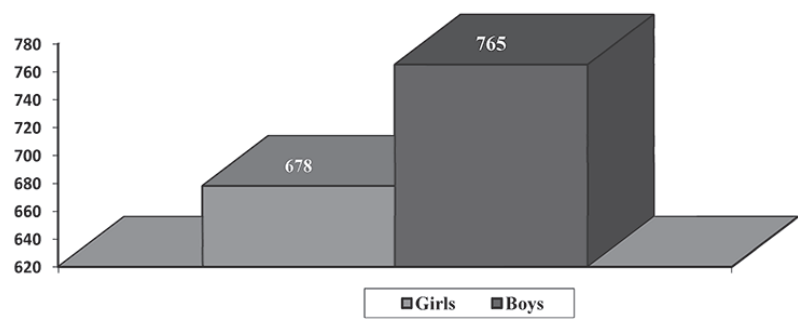

Fig. 4. Gender characteristics of pupils'views on selfconfidence as a factor of professional success

status of their families; economic and socio-political circumstances. The nature of these representations is as follows: dissipative (unclear, devoid of specific content); conformal (relaying authoritative thoughts); pragmatic ("professional growth" is more associated with administrative rather than professional careers; "professional success" is more related to prestige and social status rather than social responsibility; the need for power is connected with the pursuit of greater rights and privileges rather than socially relevant actions).

These data are of paramount interest in the context of developing entrepreneurial competency since they reflect the weak value matrix of pupils from professional (vocational) education schools, as well as the poor personal qualities required to open and run their businesses successfully.

This is mainly due to the fact that, following current regulations, the requirements for a socio-humanistic component of future specialists' professional training are advisory. As a result, social sciences and humanities are often perceived as "secondary" and "optional" in professional (vocational) education. Therefore, the quality of developing pupils' personal traits and qualities necessary for developing entrepreneurial competency traditionally depends on psycho-pedagogical culture and values of leaders of educational institutions and teachers (Yershova, 2017, pp. $25 ; 218 \mathrm{a}$, pp. 25$)$.

The time-related aspect of this problem is the conservatism of the education system itself. Traditional formal education fails to follow the intense changes caused by the digital revolution. This causes a rapid decline in the prestige of education in many industries (Yershov, 2018, pp. 76). Analytical materials from specific reputable Internet resources (Eurostat Educational Statistics, UNESCO Database, HeadHunter) prove that the authority of very time-consuming formal education is declining rapidly. For one, $56 \%$ of IT specialists aged 26 to 35 do not have a university degree since they prefer non-formal and informal education, which gives them the necessary skills and knowledge in a much shorter time. Employers of many IT companies are more interested in recruiting employees who have certificates from popular courses rather than university degrees. The HeadHunter Research Center reports that Ukrainian employees rank a university degree in IT only fifth most influential factor for successful employment. The widespread dissemination of detailed workshops for completing many professional tasks using the latest materials and innovative equipment on the Internet often pose a severe competition with not quite modern methods and technologies used in many professional (vocational) education schools.

Besides, the formal education system has not yet been able to harmonize the development of professional and key (flexible) skills that have a decisive influence on specialists' ability to rely on their resources and implement a programme of personal and professional growth (Seredina, 2018, pp. 95; Odnoroh, 2018, pp. 105; Lemeshko, 2018, pp. 101). In the system of formal education, the process of developing digital skills and culture of pupils remains problematic as well (Bazeliuk, 2018; 2019; Yershov, 2019), which are very important for developing entrepreneurial competency. Underestimating the role of key skills in professional training of future specialists can lead to several consequences impeding the development of young people's readiness for personal and professional success. These include graduates' lack of relevant knowledge about intellectual, physical and emotional reserves of the individual's development; the underdeveloped "self-concept", manifested by lack of self-observation, self-analysis, self-regulation, self-control and self-improvement; lack of time management needed to build a personal and professional growth programme.

The employees from the Institute of VET of the NAES of Ukraine have developed and released a programme of the course in the basics of innovative entrepreneurship for professional (vocational) education schools to solve this problem. This program aims to deepen the knowledge and skills of pupils from professional (vocational) education schools about entrepreneurship when studying the courses in general economics and fundamentals of sector economics and entrepreneurship.

The educational course aims to develop entrepreneurial competency in pupils as a basis for successful professional self-realization, which will promote self-employment of young specialists, help them manage their lives and careers, stimulate active par- 
ticipation in the economic and socio-political life of their country. Besides, it intends to develop a system of knowledge in the field of innovation economics, communication competency, social responsibility, self-knowledge and self-management skills.

Self-management is one of eight modules of the programme, which includes such topics as time-management, self-management and life-management. The first topic includes information about the characteristics of time as a resource; interviewing and negotiation technology; the basic requirements for workplace organization; identification of time consumers; working out an agenda; keeping a business diary. The second topic involves personality development; cognitive activity; temperament and character; emotions and volition; communication, aspirations and self-esteem of the individual; self-concept; limitations and incentives for personal development; conflicts in activities of entrepreneurs, their causes, consequences and ways of solving. The third topic aims to contribute to understanding the essence of personal and professional career; determining the individual's creative potential and vital, operational, tactical and strategic goals, individual style of management; implementation of life and career development planning; building strategies for their development; planning a job interview.

Other modules of the programme are closely linked to the development of future specialists' key competencies and ability to engage in self-management necessary to start and run their business. For one, the module, titled "Theoretical Foundations of Innovative Entrepreneurship" familiarizes pupils with the methods of generation, evaluation and presentation of innovative entrepreneurial ideas.

The module, titled "Planning Successful Business" reveals the content of the following critical psycho-pedagogical problems: building a successful image of an entrepreneur (developing readiness to succeed, understand and evaluate one's abilities; self-confidence); planning entrepreneurial success (a code of entrepreneurial behaviour, entrepreneurial culture, building strategies and tactics for success).

The module, titled "Communication in Business" presents information on verbal and non-verbal communication, communication technologies of self-presentation and reveals the communicative nature of business (stereotypes in business communication, communication barriers and solutions to them, manipulations in business communication).

The module, titled "Entrepreneurship Ethics and Corporate Social Responsibility" aims to familiarize pupils with ethical standards of human resources management and social responsibility in business.

Thus, graduates from professional (vocational) education schools can familiarize themselves with the main components of self-management: gnostic (reinforcing cognition, developing capability for self-observation and self-analysis), designing (promoting self-determination, self-prediction), communicative (involving the development of an internal strategy for interaction with other people, self-presentation, self-programming), organizational (organizing internal and external reserves of personality development), constructive (self-evaluation, self-control, self-correction, self-development).

Self-management must consist of several stages. At the first stage, pupils should learn to understand themselves, evaluate their abilities, explore the conditions of their educational and future professional and entrepreneurial activities, feel self-motived to open their business. At the second stage, they need to learn to make management decisions. At the third stage, they must learn how to plan algorithms of practical business actions, build a strategy of personal and professional development and develop business projects. At the fourth stage, it is essential for them to practically implement the stages of the developed strategy and their business ideas. At the fifth stage, they should be able to analyze the quality of the completed strategic goals of the self-development programme and evaluate the effectiveness of the completed business ideas and business projects.

Conclusions. The analyzed international and national documents emphasize the importance of developing career, entrepreneurial and other key competencies as crucial for educating a proactive personality and building a successful and economically independent state. In Ukraine, there is a discrepancy between the analyzed importance of entrepreneurial competency and the conditions for developing this competency in Ukrainian professional (vocational) education schools. It is vital to prepare young people to use their personal and time resources rationally. Self-management, which aims to provide pupils with appropriate psycho-pedagogical tools to start their business and be successful in business, is one of the most optimal for developing entrepreneurial competency under the conditions of small business development. The programme, titled "The Basics of Innovative Entrepreneurship" has been developed to overcome the imbalance between the development of professional and key competencies and the improvement of psycho-pedagogical and legal training of young specialists for self-employment under the conditions of changing market relations. Its essential component is self-management technology. The paper also presents the main components of this technology (gnostic, designing, communicative, organizational, constructive), as well as the stages of its implemen-tation. Further research should pay specific attention to the content and conditions of using self-management in professional (vocational) education schools. 


\section{List of References}

Базелюк, О., 2018. Зміст і структура цифрової культури педагогічних працівників закладів професійної освіти. Науковий вісник Інституту професійно-технічної освіти НАПН України. Професійна педагогіка, 16, с. 81-87. DOI: http://doi.org/10.32835/2223-5752.2018.16.81-87.

Базелюк, О.В., 2019. Цифровізація професійної освіти як глобальний соціоприродній процес. В: Інформаційно-ц̧ифровий освітній простір Украӥни: трансформаційні проиеси і перспективи розвитку. Програма методологічного семінару (Київ, Україна, 4 Квітень 2019). К.: Інститут інформаційних технологій і засобів навчання НАПН України.

Дратвер, Б., Закатнов, Д., Мачуський, В. та Пасічник Н., 2004. Основи підприємницької діяльності: навчальний посібник. Кіровоград: Поліграфічно-видавничий центр «Імекс-ЛТД».

Єршова, Л., 2015. Формування референтної особистості як проблема освітньої практики сучасної України. Вісник Черкаського університету. Серія: Педагогічні науки, 6, с. 119-124.

Сршова, Л., 2017. Макроекономічні фактори впливу на розвиток професійної кар'єри учнів професійно-технічних навчальних закладів. Науковий вісник Інституту професійно-технічної освіти НАПН Украӥни. Професійна педагогіка, 13, с. 22-29.

Єршова, Л., 2018 а. Соціально-психологічні фактори впливу на розвиток професійної кар'єри учнів професійно-технічних навчальних закладів. Науковий вісник Інституту професійно-технічної освіти НАПН України. Професійна педагогіка, 14, с. 22-29. https://doi.org/10.32835/2223-5752.2017.14.22-29.

Єршова, Л., 2018 b. Від купця - до підприємця: трансформація цінностей української економічної еліти у XIX - на початку XX століття. Науковий вісник Інституту професійно-технічної освіти НАПН Украӥни. Професійна педагогіка, 15, с. 154-161. https://doi.org/10.32835/2223-5752.2018.15.

Сршова, Л., 2018 с. Трансформація системи цінностей учнівської і студентської молоді в контексті реформування вітчизняної професійної освіти. Науковий вісник Інституту професійно-технічної освіти НАПН України. Професійна педагогіка, 16, с. 162-168. DOI: http://doi.org/10.32835/2223-5752.2018.16.162-168.

Сршов, М.-О., 2018. Роль української ІТ-освіти на світовому ринку інформаційних товарів і послуг. Науковий вісник Інституту професійно-технічної освіти НАПН Украӥни. Професійна педагогіка, 16, c. 74-81. DOI: http:// doi.org/10.32835/2223-5752.2018.16.74-81.

Закатнов, Д.О., 2007. Організаційно-педагогічне забезпечення підготовки учнівської молоді до планування кар'єри. Теоретико-методичні проблеми виховання дітей та учнівської молоді, 10 (II), с. 373-381.

Закатнов, Д.О., 2009. Стан і проблеми професійної орієнтації. Професійно-технічна освіта: інноваційний досвід, перспективи, 1(6), с. 173-179.

Закатнов, Д., 2015. Профорієнтаційні засади кар'єрного розвитку учнівської молоді. Науковий вісник Інституту професійно-технічної освіти НАПН України. Професійна педагогіка, 9, с. 86-94.

Закатнов, Д.О., 2017. Державний реєстраційний номер: 0116U003567. Проектування системи консультування з професійної кар'єри учнів професійно-технічних навчальних закладів. Лабораторія професійної кар'єри, IПТО НАПН України, переглянуто 15 Жовтень 2019.

Лемешко, Л., 2016. Формування художньо-творчої компетентності техніків-конструкторів одягу як проблема професійної педагогіки. Науковий вісник Інституту професійно-технічної освіти НАПН Украӥни. Професійна педагогіка, 16, с. 100-104. https://doi.org/10.32835/2223-5752.2018.16.100-104.

Однорог, Г., 2018. Теоретичні засади формування ключових компетентностей учнів у закладах професійної освіти засобами інтерактивних технологій. Науковий вісник Інституту професійно-технічної освіти НАПН Украӥни. Професійна педагогіка, 16, с. 104-108. https://doi.org/10.32835/2223-5752.2018.16.104-108.

Радкевич, О.П., 2012а. Конфіденційність персональної інформації у соціальних мережах. Вісник Вищої ради юстииіï, 3(11), с. 215-223.

Радкевич, О.П., 2012b. Забезпечення охорони і захисту персональної інформації у Сполучених Штатах Америки та Великій Британії. Вісник Вищзої ради юстиції, 1(9), с. 141-153.

Радкевич, В., 2016. Теоретичні та методичні засади розвитку професійної освіти і навчання: результати, проблеми, перспективи. Науковий вісник Інституту професійно-технічної освіти НАПН України. Професійна педагогіка, 11, с. $5-22$

Середіна, І., 2018. Підприємницька компетентність майбутніх бакалаврів з економіки підприємництва як науково-педагогічна проблема. Науковий вісник Інституту професійно-технічної освіти НАПН Украӥни. Професійна педагогіка, 16, с. 94-96.

Яблуновська, К., 2018. Теоретичні основи формування екологічної компетентності майбутніх викладачів аграрних закладів вищої освіти. Науковий вісник Інституту професійно-технічної освіти НАПН Украӥни. Професійна педагогіка, 15, с. 47-53. https://doi.org/10.32835/2223-5752.2018.15.47-53.

Yershov, M.-O., 2019. Digitalisation of professional (vocational) and pre-high tertiary education of Ukraine: problems and prospects. Scientific herald of the Institute of vocational education and training of NAES of Ukraine. Professional Pedagogy, 1(18), pp. 67-74. https://doi.org/10.32835/2223-5752.2019.18.67-74.

\section{Translated \& Transliterated}

Bazeliuk, O., 2018. Zmist i struktura tsyfrovoi kultury pedahohichnykh pratsivnykiv zakladiv profesiinoi osvity [Content and structure of digital culture of VET institutions' teachers]. Naukovyi visnyk Instytutu profesiino-tekhnichnoi osvity NAPS Ukrainy. Profesiina pedahohika [Scientific herald of the Institute of vocational education and training of NAES of Ukraine. Professional Pedagogy], 16, s. 81-87. DOI: http://doi.org/10.32835/2223-5752.2018.16.81-87, [in Ukrainian]. 
Bazeliuk, O.V., 2019. Tsyfrovizatsiia profesiinoi osvity yak hlobalnyi sotsiopryrodnii protses [Professional education transformation as a glibal socio-natural protest]. V: Informatsiino-tsyfrovyi osvitnii prostir Ukrainy: transformatsiini protsesy i perspektyvy rozvytku. Prohrama metodolohichnoho seminaru [Information-digital education environment of Ukraine: transformation protests and development prospects] (Kyiv, Ukraine, 4 Kviten 2019). K.: Instytut informatsiinykh tekhnolohii i zasobiv navchannia NAES Ukrainy, [in Ukrainian].

Dratver, B., Zakatnov, D., Machuskyi, V. ta Pasichnyk N., 2004. Osnovy pidpryiemnytskoi diialnosti: navchalnyi posibnyk [The basics of entrepreneurial activities: a textbook]. Kirovohrad: Polihrafichno-vydavnychyi tsentr «ImeksLTD», [in Ukrainian].

Yershova, L., 2015. Formuvannia referentnoi osobystosti yak problema osvitnoi praktyky suchasnoi Ukrainy [The reference individual formation as a problem of the educational practices in modern Ukraine]. Visnyk Cherkaskoho universytetu. Seriia: Pedahohichni nauky [Cherkasy university bulletin: Pedagogical sciences], 6, s. 119-124, [in Ukrainian].

Yershova, L., 2017. Makroekonomichni faktory vplyvu na rozvytok profesiinoi kariery uchniv profesiino-tekhnichnykh navchalnykh zakladiv [Macroeconomic factors of influence on professional career development of vet institutions students]. Naukovyi visnyk Instytutu profesiino-tekhnichnoi osvity NAPN Ukrainy. Profesiina pedahohika [Scientific herald of the Institute of vocational education and training of NAES of Ukraine. Professional Pedagogy], 13, s. 22-29, [in Ukrainian].

Yershova, L., 2018 a. Sotsialno-psykholohichni faktory vplyvu na rozvytok profesiinoi kariery uchniv profesiinotekhnichnykh navchalnykh zakladiv [Socio-Psychological Factors of Influence on Professional Career of Students of Vocational Schools]. Naukovyi visnyk Instytutu profesiino-tekhnichnoi osvity NAPN Ukrainy. Profesiina pedahohika [Scientific herald of the Institute of vocational education and training of NAES of Ukraine. Professional Pedagogy], 14, s. 22-29. https://doi.org/10.32835/2223-5752.2017.14.22-29, [in Ukrainian].

Yershova, L., 2018b. Vid kuptsia - do pidpryiemtsia: transformatsiia tsinnostei ukrainskoi ekonomichnoi elity u XIX - na pochatku XX stolittia [From a tradesman to an entrepreneur: the Ukrainian business leaders' values transformation in XIX and early XX centuries]. Naukovyi visnyk Instytutu profesiino-tekhnichnoi osvity NAPS Ukrainy. Profesiina pedahohika [Scientific herald of the Institute of vocational education and training of NAES of Ukraine. Professional Pedagogy], 15, s. 154-161, [in Ukrainian].

Yershova, L., 2018c. Transformatsiia systemy tsinnostei uchnivskoi i studentskoi molodi v konteksti reformuvannia vitchyznianoi profesiinoi osvity [Transformation of the students' values system in the context of domestic vocational education and training reforming]. Naukovyi visnyk Instytutu profesiino-tekhnichnoi osvity NAPS Ukrainy. Profesiina pedahohika [Scientific herald of the Institute of vocational education and training of NAES of Ukraine. Professional Pedagogy], 16, s. 162-168. DOI: http://doi.org/10.32835/2223-5752.2018.16.162-168, [in Ukrainian].

Yershov, M.-O., 2018. Rol ukrainskoi IT-osvity na svitovomu rynku informatsiinykh tovariv i posluh [The role of Ukrainian IT education in the world market of information products and services]. Naukovyi visnyk Instytutu profesiinotekhnichnoi osvity NAPS Ukrainy. Profesiina pedahohika [Scientific herald of the Institute of vocational education and training of NAES of Ukraine. Professional Pedagogy], 16, s. 74-81. DOI: http://doi.org/10.32835/2223-5752.2018.16.7481, [in Ukrainian].

Zakatnov, D.O., 2007. Orhanizatsiino-pedahohichne zabezpechennia pidhotovky uchnivskoi molodi do planuvannia kariery [Organizational and pedagogical support of training pupils to build a career]. V: Teoretyko-metodychni problemy vykhovannia ditei ta uchnivskoi molodi: zb. nauk. pr. [Theoretical and methodical problems in character building of children and pupils]. K.: In-t problem vykhovannia APN Ukrainy, s. 373-380, [in Ukrainian].

Zakatnov, D.O., 2009. Stan i problemy profesiinoi oriientatsii [The conditions and problems of professional orientation]. Profesiino-tekhnichna osvita: innovatsiinyi dosvid, perspektyvy [Professional (vocational) education: an innovative experience and prospects], 1(6), s. 173-179, [in Ukrainian].

Zakatnov, D., 2015. Proforiientatsiini zasady kariernoho rozvytku uchnivskoi molodi [Professional orientation and proforientologic competences concerning vocational self-determination and career development of young students]. Naukovyi visnyk Instytutu profesiino-tekhnichnoi osvity NAPS Ukrainy. Profesiina pedahohika [Scientific herald of the Institute of vocational education and training of NAES of Ukraine. Professional Pedagogy], 9, s. 86-94, [in Ukrainian].

Zakatnov, D.O., 2017. Derzhavnyi reiestratsiinyi nomer: 0116U003567. Proektuvannia systemy konsultuvannia z profesiinoi kariery uchniv profesiino-tekhnichnykh navchalnykh zakladiv [Designing a system of career counselling for pupils from professional (vocational) education schools]. Laboratoriia profesiinoi kariery, IPTO NAPN Ukrainy, perehlianuto 15 Zhovten 2019, [in Ukrainian].

Lemeshko L., 2018. Formuvannia khudozhno-tvorchoi kompetentnosti tekhnikiv-konstruktoriv odiahu yak problema profesiinoi pedahohiky [Forming clothes technicians-constructors' arts-creative competence as a professional pedagogy problem]. Naukovyi visnyk Instytutu profesiino-tekhnichnoi osvity NAPN Ukrainy. Profesiina pedahohika [Scientific herald of the Institute of vocational education and training of NAES of Ukraine. Professional Pedagogy], 16, s. 100-104. https:// doi.org/10.32835/2223-5752.2018.16.100-104, [in Ukrainian].

Odnoroh, H., 2018. Teoretychni zasady formuvannia kliuchovykh kompetentnostei uchniv u zakladakh profesiinoi osvity zasobamy interaktyvnykh tekhnolohii [The essence and structure of key competencies of future skilled sewing workers]. Naukovyi visnyk Instytutu profesiino-tekhnichnoi osvity NAPN Ukrainy. Profesiina pedahohika [Scientific herald of the Institute of vocational education and training of NAES of Ukraine. Professional Pedagogy], 16, s. 104-108. https://doi. org/10.32835/2223-5752.2018.16.104-108, [in Ukrainian].

Radkevych, O.P., 2012a. Konfidentsiinist personalnoi informatsii u sotsialnykh merezhakh [Privacy of personal information in social networks]. Visnyk Vyshchoi rady yustytsii [Bulletin of the High Council of Justice], 3(11), s. 215223, [in Ukrainian].

Radkevych, O.P., 2012b. Zabezpechennia okhorony i zakhystu personalnoi informatsii u Spoluchenykh Shtatakh Ameryky ta Velykii Brytanii [Ensuring the safety and protection of personal information in the United States and Great Britain]. Visnyk Vyshchoi rady yustytsii [Bulletin of the High Council of Justice], 1(9), s. 141-153, [in Ukrainian]. 
Radkevych, V., 2016. Teoretychni ta metodychni zasady rozvytku profesiinoi osvity i navchannia: rezultaty, problemy, perspektyvy [Theoretical and methodological basis of VETdevelopment: results, problems, prospective]. Naukovyi visnyk Instytutu profesiino-tekhnichnoi osvity NAPN Ukrainy. Profesiina pedahohika [Scientific herald of the Institute of vocational education and training of NAES of Ukraine. Professional Pedagogy], 11, s. 5-22, [in Ukrainian].

Seredina, I., 2018. Pidpryiemnytska kompetentnist maibutnikh bakalavriv z ekonomiky pidpryiemnytstva yak naukovopedahohichna problema[Entrepreneurial competence of future bachelors in business economics as a scientific and pedagogical problem]. Naukovyi visnyk Instytutu profesiino-tekhnichnoi osvity NAPN Ukrainy. Profesiina pedahohika[Scientific herald of the Institute of vocational education and training of NAES of Ukraine. Professional Pedagogy], 16, s. 94-96. https:// doi.org/10.32835/2223-5752.2018.16.104-108, [in Ukrainian].

Yablunovska, K., 2018. Teoretychni osnovy formuvannia ekolohichnoi kompetentnosti maibutnikh vykladachiv ahrarnykh zakladiv vyshchoi osvity [Theoretical bases of forming the ecological competence of the agrarian higher education institutions' future academic staff]. Naukovyi visnyk Instytutu profesiino-tekhnichnoi osvity NAPN Ukrainy. Profesiina pedahohika [Scientific herald of the Institute of vocational education and training of NAES of Ukraine. Professional Pedagogy], 15, s. 47-53. https://doi.org/10.32835/2223-5752.2018.15.47-53, [in Ukrainian].

Yershov, M.-O., 2019. Digitalisation of professional (vocational) and pre-high tertiary education of Ukraine: problems and prospects. Scientific herald of the Institute of vocational education and training of NAES of Ukraine. Professional Pedagogy, 1(18), pp. 67-74. https://doi.org/10.32835/2223-5752.2019.18.67-74, [in English].

\section{Розвиток підприсмницької компетентності майбутніх кваліфікованих фахівців із використанням технології самоменеджменту}

Людмила Єршова,

доктор педагогічних наук, доцент, заступник директора ІПТО НАПН України

\section{Реферат.}

Актуальність: реформування в Україні ринкових відносин детермінує зміни в системи вітчизняної професійної освіти, зокрема необхідність забезпечення підготовки молодих фахівців до успішної особистісної та професійної самореалізації в умовах розвитку малого бізнесу.

Mета: теоретично обгрунтувати доцільність використання технології самоменеджменту в процесі розвитку підприємницької компетентності майбутніх кваліфікованих фахівців в умовах зміни в Україні ринкових відносин та інтенсивного розвитку малого бізнесу.

Методи: зовнішній аналіз відібраних джерел (для визначення історичних обставин і мотивів їх створення та функціонування як елементів певних суспільних відносин), і внутрішній аналіз (вивчення особливостей певного документа).

Результати: показано, що зміна економічних відносин зумовлює активні трансформаційні зрушення в системі цінностей сучасної учнівської молоді; в умовах переходу від суспільства постіндустріального до інформаційного, що характеризується інноваційністю і стрімкою зміною умов праці, доленосного значення для молодих фахівців набуває категорія часу; ключовою навичкою молодого покоління впевнено стає самоменеджмент - раціональне управління часом, розвитком власної особистості і свого життя; міжнародні та вітчизняні документи акцентують увагу на важливості формування кар'єрної, підприємницької та інших ключових компетентностей особистості, необхідних для побудови успішної професійної кар'єри, реалізації самозанятості молодих фахівців в умовах розвитку малого бізнесу; водночас у вітчизняних закладах професійної освіти недосконалою є підготовка молоді до раціонального використання власних особистісних і часових ресурсів.

Висновки: однією з найбільш перспективних для реалізації завдань формування підприємницької компетентності в умовах розвитку малого бізнесу є технологія самоменеджменту; з метою подолання дисбалансу між формуванням професійних та ключових компетентностей, удосконалення психолого-педагогічної та правової підготовки молоді до самозайнятості в умовах зміни ринкових відносин створено програму «Основу інноваційного підприємництва», важливою складовою якої є технологія самоменеджменту; охарактеризовано основні компоненти технології (гностичний, проектувальний, комунікативний, організаційний, конструктивний) та етапи реалізації.

Ключові слова: професійна освіта, самоменеджмент, ключові компетентності, кар'єрна компетентність, підприємницька компетентність. 